\title{
Interlinking Service Delivery Innovation And Service Quality: A Conceptual Framework
}

Arif Mohammad Arshad, Xi'an Jiaotong University, China

Qin Su, Xi'an Jiaotong University, China

\begin{abstract}
The purpose of writing this paper is to present the relationship between service delivery innovation and service quality in service organizations and to establish a research conceptual framework about this relationship. There are few studies that illustrate the relationship between service delivery innovation and its impact on service quality. This paper theoretically examines the antecedents and consequences of service delivery innovation and its influence on service quality. Authors suggest that customer service is an important mediator between service delivery innovation and service quality which affects the service quality of a firm. The recommended framework and its relationships with service quality present practical guidance for service managers to observe their service delivery in an effort to improve service quality by delivering superior customer service for their customers in a distinctive manner that leads to enhances firm's competitiveness.
\end{abstract}

Keywords: Service Delivery Innovation; Service Quality; Customer Service; Service-Domain Logic

\section{INTRODUCTION}

( $\mathrm{n}$ today's economy, the service sector is of great importance regarding its share in supporting the world's economy and is observed as the competitive resource for differentiation that is hard to be copied by the competitors (Zeithaml and Bitner, 2000). Service organizations region over plenty of world economics and are constantly changing in response to the opportunities and challenges brought up to them by globalisation, technological innovations and Competitors. Dealing with quality and innovation enhancement in services is consequently complicated and is multidisciplinary, comprising of finance, marketing, operations and information technology. Service quality plays an integrating role between the organization and its customers because service quality is the result of internal organizational procedures and strategies that are extremely crucial in the service sequence that leads to customer satisfaction, customer value, and loyalty (Dean, 2002). A nicely developed service which is eye-catching can offer the firm with critical factors of differentiation from rivals. An efficiently served service along with impressive results can bring on praiseworthy service quality and brand image feedbacks (Bitner et al., 2008).

In a very short time, economic globalisation has transformed the world's economic order, delivering with it completely new business challenges and opportunities. Customers are evolving into a lot more refined, segmented and challenging, and are expecting more regarding product or service customization, uniqueness, price and quality (Stark, 2011). The demand for quality and innovation in services firms are becoming very important regarding their business superiority in order to remain competitive by enhancing their competitive advantage (Bon \& Mustafa, 2013). Innovation has been a leading element in sustaining global competitiveness. It heats up organizational development, propels future triumphs and it is the vehicle that enables businesses to support their stability in international economy (Gaynor, 2002). Firms deal with challenges to distinguish themselves in the industry by becoming innovative. They endeavour to come up with realistic choices concerning the identification, selection, and utilization of resources to develop differentiated new products and services which will bring about outstanding profits (Nijssen et al., 2006). 
Service innovation is one of approaches for building a competitive edge in an extremely challenging environment. Service innovation evolves into a productive way for an organization to speed up its rate of growth and profitability (Berry et al., 2006). Innovation entails an approach to take advantage of new concepts effectively in an effort to enhance competitive positioning in the industry. Also, past researches in numerous industries proved that competition leads to service innovation, which could lead to in superior customer satisfaction (Danjum \& Rasli, 2012). Service innovation includes intangible resources for a more radical service logic outlook that focuses on nontraditional characteristics based on viewpoint of service delivery designs (Blazevic \& Lievens, 2008; Verma \& Jayasimha, 2014). It goes past the traditional limitations of product innovativeness and includes acceptance of enhanced service processes by means of designing and creating new service delivery systems (Avlontis et al., 2001; Verma \& Jayasimha, 2014).

Service delivery describes a firm's capability to create finished components' and deliver services/ products to the customers (Zeithaml et al., 1988; Chen \& Tsou, 2012). A firm's capability to provide targeted amount of quality, customization, speed and the cost for available resources is determined by both the amount of work completed prior to demand and exactly how the firm facilitates consumers to take advantage of its resources (Chopra and Lariviere, 2005). In the today's economy, due to fast changing consumer tastes as well as the growth of variety of consumer segments with diverse preferences, values, and shopping habits, firms aim to offer services and products at low costs, provide better value to customers, and enhance service delivery strategies to boost sales and profits and cut down costs( Chen et al., 2009). Organizations are more likely in a position to catch the attention of new customers due to enhanced or excellent service quality as well as their capability to promote these improvements (Johnston and Clark, 2001). However, it is frequently asserted that majority of service firms currently deliver products and services to their customers by using very identical approaches. They give attention to specific areas of service delivery, for instance design, capacity, performance measurement or service strategy creation. Managers do not insert sufficient time and endeavour into either identifying the service strategy and service delivery or acquiring comments in regards to what they think to become an acceptable standard of service. Inadequate resources could possibly be the consequence of an inadequate knowledge of market needs or demands. Managers often claim a perspective that the organization is unable to devote enough time and bother to know exactly what its customers really want and hence the service design process is problematic from the beginning. This goes into inadequate or unacceptable service design to cause sub-standard resource allocation. Incompatible targets could be the outcomes of the wrong marketing claims made by the organization that can't be served, or incorrect word-ofmouth referrals or organizational reputation that could possibly be a consequence of low-quality service experiences in the past(Johnston and Clark, 2001).

Service innovation is designed to set up new markets by means of innovating service delivery and as a consequence stretching out firm's service range. Organizations should understand their targets and deal with these targets in a proper way. In order to attain an excellent service positioning, service firms need to deliver services and products by means of distribution techniques in new innovative ways that make use of their unique competences like knowledge and skills. In fact, the innovative usage of delivery methods is a lot more turning into a completely new resource for differentiation and innovation for firms (Wiertz et al., 2004; Chen \& Huang, 2009).

There is still deficiency of evidence of importance of innovation in service delivery (Chen et al., 2009). Also, there isn't any complete and satisfactory knowledge of service delivery innovation and its precise role in the delivery of service quality. The objective of paper is to contribute to the existing literature on service delivery innovation by a building a framework that aims to illustrate the facts that drives service delivery innovation and, consequently affects firms service quality. This paper proposes a model that illustrates the antecedents and consequences of service delivery innovation in accordance with key facts of the service-dominant logic and their relationship with service quality.

\section{THEORATICAL FRAMEWORK AND HYPOTHESIS DEVELOPMENT}

\section{Service-Domain Logic (S-D Logic)}

Service-domain logic (S-D logic) proposes a framework for visualizing a lot more precisely, regarding the perception of services and its place in exchange and competition. S-D logic perceives applied professional 
competencies and knowledge as the peoples' substitute the services in an attempt to enhance the society's welfare. As opposed to conventional goods-dominant (G-D) logic, service in S-D logic stands out as implementation of professional capabilities like skills and knowledge (Lusch et al., 2007; Chen et al., 2009). S-D logic is based on collective understanding of individuals and firms, put together into networks and communities, devoted to interchanging the functional utilization of their competences for their own well-being (Lusch et al., 2007). In S-D logic the tasks of organizations and consumers aren't exclusive, which means that value is actually co-created collectively and reciprocally, in interaction among suppliers and the customers via the integration of resources and making use of competences (Vargo et al., 2008). Competing via services is about much more than introducing value to products. Notably, it could be much more than the combined features of marketing, information-systems, strategic business, human resource, operations management and financial to manufacture and deliver superior quality products(Lusch et al., 2007; Vargo and Lusch, 2004). According to S-D logic Knowledge and skills are crucial resources for achieving competitive edge. The essence of the difference between S-D logic and G-D logic is based on premise of exchange. S-D logic is based on the actions of operant resources like knowledge and skills, while G-D logic is based on the exchange of operand resources like goods (Vargo and Lusch, 2004; Vargo et al., 2008).

S-D logic is based on the present day work of Hunt's (2000) resource-advantage (R-A) theory. R-A theory acknowledges that competitive advantage is influenced by the delivery of outstanding competences. The today's business world is very dynamic; it's unpractical for a firm to be stagnant in the delivery of their value propositions presented services. Therefore, service innovations are important and are based on the range of competences that a firm continuously rekindle, build, incorporate, and renovate. However, due to the integrative nature of service delivery, collaborative competence, according to S-D logic plays most critical role in order to enjoy sustained competitive advantage (Lusch et al., 2007). Applying S-D logic and R-A theory, we put emphasis on operant resources and their effect on service quality. Our model focuses on three sources of service innovation; IT capability, Relationship \& knowledge networks and dynamic capabilities..

\section{Service Quality}

Service quality is a perceived judgment in the offering of a service. It comes from assessing customer expectations considering the degree of service, customers believe to have experienced (Parasuraman, Zeithaml, \& Berry, 2002). It is conformance to customer specifications during offering of a service. The measure of quality in service sector offering has turned out to be more challenging. Service quality is the customer's overall judgement of quality of service offering (Santos, 2003). Service quality is also influenced by capability of an organization in satisfying customer needs in accordance with their expectations (Yoo \& Park, 2007). Services are usually performance driven, therefore creating accurate descriptions to a homogeneous quality is challenging to be determine (Kettinger \& Lee, 1 994). Three factors play dominant role in the marketing environment: growing rivalry from private firms, introduction of new sophisticated technologies, and continuous change in the working environment. Customers have grown to be increasingly conscious of their wants and desire better standards of services. Due to increased awareness, customers' targets are continuously changing and it has become hard for service firms to successfully measure and organize their services. The service firms in order to improve their customer service management, they should pay more attention to enhancing the service selectively as well as focusing on more important service features. It is important for service firms to know how delicate the customers are to numerous service features or measurements. Therefore, they should allocate resources in such a way that boost the usefulness of service operations and are in line with customer concerns. Moreover, the priorities of customer service should be fully investigated keeping in view the service specific contexts (Sachdev \& Verma, 2004).

Due to technological advancements and competition, etc. customer service of service firms is under tremendous pressure. Customers are more refined for their demands and therefore are more asserting on better standards of service. In their minds service signifies customer relationship, service delivery, customer delight, customer satisfaction, etc. The service firms ought to give consideration to the significance of service quality parameters, for example tangibles, empathy, assurance, responsiveness and reliability, while considering about degrees of performance in achieving customer service targets. Customer service endeavours are, therefore, strongly linked to quality enhancement pursuits (Sachdev \& Verma, 2004). Service quality is an important tool in in measuring customer satisfaction as well as differentiating products and services. The relationship between service 
quality and customer satisfaction is found to be very strong and this relationship can be protected by providing the products or services with significant quality (Kadir et al., 2011).

Parasuraman et al. (1988) developed a scale to measure the service quality of different service providers. It is one of the fundamental instruments used to measure perceived service quality and has been verified by numerous past studies. The aim of SERVQUAL model was to measure the customer expectations of different dimensions of service quality and the perception of quality actually received by the customer (Samat et al., 2006). As a consequence they developed SERVQUAL instrument which initially contains 10 service quality dimensions and later on they were reduced to final five: empathy, assurance, responsiveness, reliability and tangibles. This model is based on the model of disconfirmation model that is dependent on the evaluation of customers' expectations regarding their experience from the service. There are 22 attributes in the SERVQUAL instrument and the customers are encouraged to express (seven-point scale from "strongly disgaree" to "Strongly agree") their experience from the service, their expectations from the service and what they perceived from the service (Grönroos, 2000). Gronoos(1983) has presented his own two dimensional model of service quality. He suggested that service quality is a function of two variables: technical quality and functional quality. The technical quality deals with what is provided whereas functional quality entails how it is provided.

\section{Relationship between IT capability and service delivery innovation}

Technologically triggered approaches of service delivery have the capability to win employees, customers as well as management (Bitner et al., 2000; Walker et al., 2002). Customers may be presented extra or even extended services, superior service convenience and command, possibly much more trusted information delivery, greater autonomy to access data and customer support services that were not available before. Using technological innovation in the shipping and delivery of services can reward both buyers as well as service firms' in the same way (Walker et al., 2002). Service delivery innovation depends immensely on technologies and it is verified that $93 \%$ of the professional services firms' survey heavily rely on service delivery innovation. Almost all of the attributes of service delivery innovation needs technological foundation which is versatile, adaptable, and reconfigurable. Furthermore, this platform ought to combine readily with outdoor methods and procedures to assist consumer and also suppliers to get the attention of international best product resources (Dawson \& Horenkamp, 2007).

Figure 1. Dimensions of IT capability

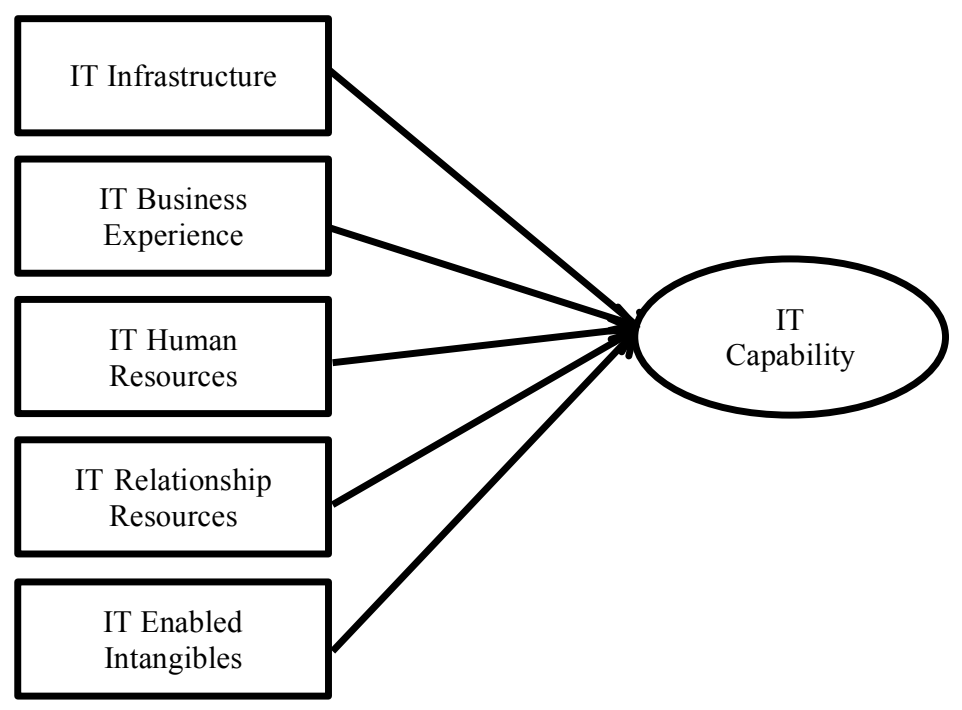

The RBV highlights the significance of constructing distinctive, inimitable and heterogeneously allocated skills being the cause of competitive advantage (Bhatt et al., 2005). We recognized five important dimensions that build the level of IT capabilities based on the past research work of Bharadwaj's (2000), Ross et al. (1996), Bassellier et al. (2003) and Bhatt and Grover (2005).These five dimensions are: IT human resources, IT 
infrastructure, IT business experience, IT relationship resources and IT-enabled intangibles. IT capability is consist of hierarchy of amalgamated operant resources including IT-enabled intangibles, human IT resources, IT infrastructure, IT business experience and IT relationship resources. Information technology facilitates companies to handle client data swiftly as well as effectively and embeds employees' unique expertise into delivery advancement functions by means of the integrated systems and also tacit human IT resources and skills (Chen \& Huang, 2009). Technological innovation can affect firm's capability to create value that may reinvent the way in which customers interface with an offering. For instance, IT boosts the company's response to client calls in reduced shipment times (Jackson, 1990) as well as facilitates customers to keep an eye on their own scheduled delivery (Chen \& Huang, 2009; Tinnilä and Vepsäläinen, 1995). So we can assume

H1: The degree of IT capability is significantly related with service delivery innovation

\section{Relationship Between Relationship and Knowledge Networks and Service Delivery Innovation}

As outlined by S-D logic, joint activities with customers, suppliers, and workers are vital for innovation. Firms through sharing create networks that could deliver additional innovations. Frequently, organizations tend to be forced to collaborate for innovation simply because they usually don't have most of the essential resources needed for innovation inside the organization (Tether 2002; Chen \& Huang, 2009). According to S-D logic, marketing is the collection of economic and social processes (Lusch and Vargo, 2006) where the prospect of interaction is of great importance. It holds the concept that value creation serves as approach of combining and remodelling resources that necessitates relationships and that means networks (Lusch \& Vargo, 2006). Innovative organizations are creating knowledge-based interactions that depend on cooperation as well as joint knowledge sharing amongst the organizations. This kind of connection leads to improvement in knowledge and capabilities for the client. The highvalue service networks are engaged in knowledge-based or collaborative relationship and banks on readiness to reveal information, mutual trust and all parties basically open to innovative solutions. In order to develop new products or create innovative ideas, mature resources from both clients and professional service firms collaborate across organizational constraints and genuinely co-create and take advantage of intellectual property. Clients in these kinds of knowledge-based relationship are usually much less troubled by price because they value the association that collaborative teams, open communication, , and supporting experienced workers perform in creating value (Dawson \& Horenkamp, 2007).

Figure 2. Research Framework

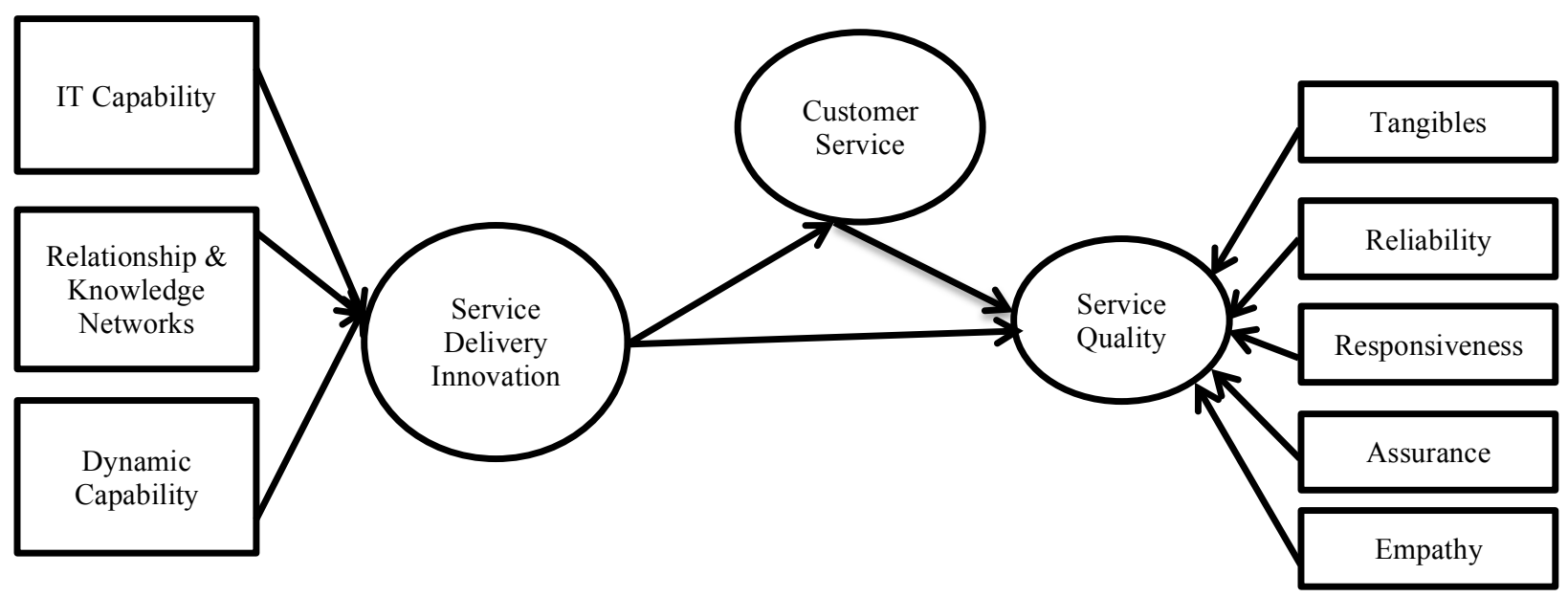

Mascitelli (2000) claims cutting-edge innovative developments are the consequence of taking advantage of tacit knowledge held by both people and team members. It is challenging to seize the innovative capability of implicit knowledge that could be attained if innovative design team members are personally engaged and emotionally dedicated during the innovation process. The firm therefore ought to support this kind of personal determination with an adequate environment as well as encouraging strategies. Mascitelli(2000) recommends two 
strategies that may work as catalysts: making use of prototypes to aid innovative thinking and face to face sharing of knowledge (SChILLING \& Werr, 2009). Leiponen $(2005 ; 2006)$ in the service innovation process stresses on the possible impact of collective knowledge. In research of knowledge demanding service firms in Finland, she demonstrates that joint utilization of knowledge is far better to bring about innovation as compared to individual employing of knowledge. As outlined by Leiponen, jointly maintained knowledge consists of both organised knowledge in terms of service solutions and team-centred skills and processes. Depending entirely on knowledgeable and innovative individuals to develop novel ideas could obstruct innovation. Leiponen also demonstrates service innovations are more inclined to originate from tacit collective knowledge whereas explicit joint knowledge contributes to service enhancements (SChILLING \& Werr, 2009; Leiponen, 2006).

Miles (2000) recognized a shift in the study of service innovation in individual service firms towards the direction of studying service innovation in innovative networks and systems. It's been pointed out that service firms that desire to be innovative should consider themselves being the part of creative networks. Czarbutzki \& Spielkamp (2003) have discovered firms with innovative networks and systems usually have a solid creative capability because they have knowledge, skills and creative thinking in marketing and management, which is essential for productive innovation. As a result, they recommend viewing business service firms as a source of innovation since they undertake the character of knowledge creators designed for customers. However, on the other hand, since several service firms clients turn out to be creative, customers have been discovered being crucial contributing factors to creativity in service firms. Customers could play a key role in service innovation by giving tips for new services products or service enhancements (SChILLING \& Werr, 2009; Matthing et al., 2004). Using font-line staff that could possibly have the day to day encounter with customers, acts like participants in the service innovation network continues to be recommended as one of the means of integrating the information from the clients during the innovation process.

Building a network of connections in the service innovation process could also probably be supported by an innovative climate. Past researchers claim that in order to become innovative, firms need to develop an organizational climate that encourages communication and relationship with customers, various internal capabilities, and other external actors (SChILLING \& Werr, 2009). As a result of supportive relationship targeted at innovation, firms could increase their capability to participate in process innovation through nurturing their relationships with customers and suppliers (Kaufman et al., 2000; Chen \& Huang, 2009). Furthermore, Simmie (1997) outlined the significance of relationship among individuals with diverse knowledge to produce innovative ideas. The communication, professional skills and good knowledge of external partners play vital role in developing creative ideas. Firms can develop better techniques of service delivery through healthier partnerships with external partners like customers or suppliers (Chen \& Huang, 2009). Hence we have following hypothesis:

H2: Relationships and knowledge networks have significant impact on service delivery innovation.

\section{Relationship Between Dynamic Capability and Service Delivery Innovation}

According to S-D logic numerous actors play role in co-creating the value (Prahalad \& Ramaswamy, 2004; Ordanini \& Parasuraman, 2011) instead of looking at value as produced by a single actor. Hence, in innovation, collaboration with employees, partners and customers are of significant importance (Chen \& Huang, 2009). According to S-D logic operant resources like knowledge and skills are important source of competitive advantage (Vargo and Lusch, 2004).

\section{Customer orientation and service delivery innovation}

Service firms with no clients can't create products or services of value. It's because the role of customer is critical in service delivery. The new service process can be developed by utilizing their resources and competences (Zeithaml, Bitner, and Gremler 2009). The accumulation and implementation of customer skills and knowledge is beneficial in provision of new services. According to S-D logic the capability to draw in customers and business partners towards the business process in order to utilize them as a mean to promote change as combined capability (Lusch, Vargo and O'Brien 2007). It's a kind of organizational culture that encourages the knowing of targeted customers and enables the consistent development of customer value (Narver and Slater, 1990). 
Figure 3. Dimensions of Dynamic capability

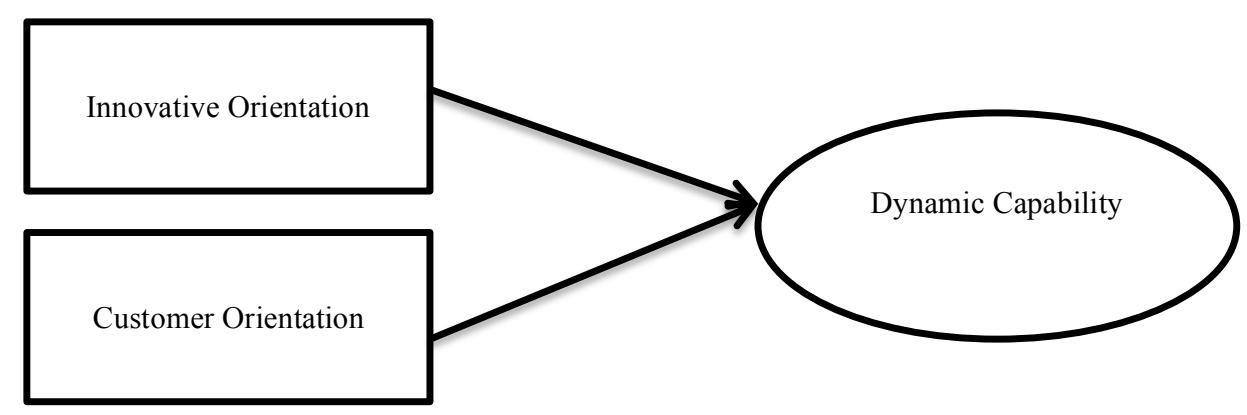

Firms employing customer orientation bring about intelligence regarding the present as well as the potential future needs associated with targeted customers and also distribute the new intelligence throughout the entire organization (Grawe et al., 2009). The creation of customer value has been associated with the service innovation. Customer value is attributed to the customer's perceived liking for a product or service after usage it because of its features as well as performance (Woodruff, 1997). The components' of the customer value depends on the market environment. These components are likely to change due to the change in market environments (Flint and Mentzer, 2000). Due to this fact, creating customer value through service innovation necessitates that firms should predict the long term customer needs and demands. Firms while creating new services, they need to foresee environmental variations in order to ensure superior value to their customers (Grawe et al., 2009; Kandampully, 2002). Service firms should take into account customers' opinions in service innovation projects. They suggest that customers may be useful resource for knowledge, particularly for verifying a preferred technical solution by taking part in testing of a construction prototype or project. Nevertheless, customers' participation in the affirmation of service innovations is apparently more difficult than to the affirmation of product innovations (Abramovici \& Bancel-Charensol, 2004; SChILLING \& Werr, 2009). Gustafsson et al. (1999) researched the potential benefits of customer participation in service innovation while investigating the Scandinavian Airlines (SAS). They researched how SAS has successfully launched new services and refurbished old services after taking opinions from customers. They monitored customers' operations and attempted to determine what customers like to accomplish while travelling through the airline. They found that airlines should involve customers during the design process rather than insisting that customers should follow the company designed process.

\section{Innovation Orientation and Service Delivery Innovation}

According to S-D logic continuous innovative endeavour which rallies a wide range of competences is important for attaining and preserving service accomplishments (Lusch,Vargo, and O'Brien 2007). According to SD logic the inherent component of innovation orientation is knowledge creation and implementation (Siguaw, Simpson, and Enz, 2006). Due to this fact, innovation orientation emphasises on understandings of values that leads to innovation which are adopting of new work practices and continuous and radical change. The innovative oriented firms encourage workers to deliver new ideas in order to keep pace with new market developments. Thus, innovation orientation signifies the importance of developing a culture that is ready to accept new ideas via using new technologies and integrated resources. Also, employees are motivated to take into account the adoption of innovation (Chen, Tsou, \& Huang, 2009). Some research studies highlight the significance of employing crossfunctional teams (Avlonitis et al., 2001), communication (Lievens \& Moenaert, 2000), including both front-line workers as well as customers (Alam, 2006) in the growth and development of new bank services (SChILLING \& Werr, 2009). According to R-A theory the behaviours of competitors and customers can affect the organizational innovation practices. Firms should leapfrog the benefits of competitors by delivering superior products and services by practising superior methods and strategies. Firms can accomplish this by developing innovative culture to offer new and current customer service successfully. They should think how to produce and build new skills and knowledge (i.e., competences) successfully for their products and services (Hurley and Hult's, 1998; Chen, Tsou, \& Huang, 2009). 
Innovation-oriented firms in order to gain the marketplace, concentrate on creation and launch of novel concepts as well as products and services. Hence, they possess the better capability to foresee customer wants and act a lot better than rivals to create critical advantages to innovation oriented firm (SIMPSON et al., 2006). According to Schlegelmilch et al., (2003) innovative firms consistently keep an eye on their opponents, they "set out to make competition irrelevant," by building the marketplace, instead of just following the competitors (Schlegelmilch et al., 2003). Hurley and Hult (1998) modelled a relationship between firm innovativeness, innovation capability and the competitive edge. They pointed out that firms can be more successful by having a better capability to innovate . They can understand their business environment in a better way and create new capability that results in competitive edge and outstanding performance (SIMPSON et al., 2006). We come up with the following hypothesis:

H3: Dynamic capability has positive significant relationship with service delivery innovation

\section{Relationship Between Service Delivery Innovation and Service Quality}

Delivering superior service quality have significant role in achieving competitive advantage. Satisfied customers not only have effect on an organization's profitability but also it leads to positive word of mouth, brand loyalty and repeat purchases. Service quality is the comparison of customer expectations with performance. Delivering service quality means fulfilling customer expectations on regular basis. During evaluating service quality customers compare the expected services with the services they receive. It is perceived judgement that is measured by comparing the customer expectations from the service with the level of the service perceived by the customer (Parasuraman et al., 2004). It has been proved from the past research that there is positive relationship between customer satisfaction and service quality. Customer satisfaction depends on the quality of service provided by the service provider and it plays dominant role in the determination of customer satisfaction (Agbor, 2011). Customer loyalty is of great importance in the current literature because it's the primary force to boost firm's financial perforamce in the current business enviornment. Superior service quality plays key role in enhancing customer loyalty. It has been proved from previous research that there is positive correlation between service quality and customer satisfaction (Cronin et al., 2000), that leads to customer loyalty (Lai et al., 2009). Service quality is also closely linked with customer's intention to adhere to the service provider (Anton et al. 2007; Bell et al. 2005).

Service innovation is an important feature of firm's capability to differentiate itself from its competitors and add more to firm's revenue. Innovations can enhance service differentiation, hence, it is essential for managers to carry out those innovations that are sought by the customers but also generate revenue for the firm (Dev et al., 2005). The recent literature found direct and positive relationship between innovation and performance in different service sectors (Ordanini and Rubera, 2010; Lin, 2011). The firms which clearly define their innovation process for services are faster and successful in developing new services. The development of new services leads to higher revenue growth as well as increase in the share of their total revenue. The companies should pay more attention to their innovation strategy and processes and especially their services in order to make innovation process more systematic (Schulteß et al., 2010). Successful innovation strategies are more useful during the recession times when there is decrease in economic activity due to fewer investments. Service innovation is a big source of competitive advantage for those companies which capitalize on knowledge gained from customers, competitors and have the potential to develop more meaningful and unique services. Today's business environment is very competitive and therefore just providing quality services is not enough, companies should seek for new innovative service offerings that are valuable for customers(Bettencourt et al., 2013)

According to different studies being innovative can lead to growth in business performance on service firms. Cainelli et al. (2004) in his studies investigated the relationship between innovation and financial performance in service firms. He found that innovative firms perform better than non-innovative firms. Matear et al. (2004) studied the performance outcomes of various resources of market advantage. They concluded that brand investments as well as new service development play key role in the achievement of positional advantage that in result leads to service firms' performance. The service firms can attain superior financial performance through differential positional advantage, innovative features and offering higher product quality (Day and Wensley, 1988). The objective of firm's innovation strategies includes improving service quality and reduces costs. (Evangelista \& Sirilli, 1998).The service organizations can also take benefit from innovation (Kelly \& Storey, 2003; Vermeulen et al., 
2003). According to (Klomp \& Storey, 2000) research based on quantitative evidence on Dutch firms, they concluded that innovation in service firms results in growth in revenue. They found that in mature and established firms, most of sales growth comes from non-price factors like design and quality. According to already available literature; it is found that service innovation not only increases the business revenue but also brings out other benefits for service firms like creating customer value and better strategic success (Vermeulen et al, 2003). It is obvious from the past research that there is positive effect of service innovation on customer's choice. A study by (Dev et al., 2005) demonstrates the effect of service innovation in the hotel industry. They found that service innovation have big impact on the guests living in economy hotels as compared to upscale hotels. They also found that innovative services like technological improvements and customization have larger impact on leisure hotels in comparison to business travellers. Lin (2011) in his study about tourism industry of China studied the impact of service innovation on firm performance through direct and indirect paths where service quality plays the mediating role. They found the positive effect of service innovation on both service quality and firm performance. Hence, we can suggest the following hypothesis

H4: Service delivery innovation has positive significant relationship with service quality.

\section{Relationship Between Service Delivery Innovation and Customer Service}

The RBV emphasis that innovation resources could impact firm's capability to create value that may enhance the viewpoint of customers regarding their communication with service offerings (Chen \& Tsou, 2012; Michel et al., 2008). The firms may transform their approach to building a customer value and possibly influence their clients' behaviours by applying innovative techniques. Innovations in service delivery are viewed as creative systems of delivery that provide customers better comfort (Lovelock and Wright 2002) and strengthen a firm's competitive position (Chen et al., 2009). According to the work of Hurley and Hult's (1998), based on R-A theory, suggests that innovative practices of the firms are influenced by the actions of competitors and customers. Therefore, these firms in order to effectively deliver customer service to current and new customers should focus on improving new knowledge and skills.

Service managers should make use of technology being an active part of their business strategy. They need to develop and cultivate a corporate culture that embraces change and innovative methods of carrying out work. Numerous organizations have built their own technology units that are employed to discover how innovations could possibly best be tailored to create customer value, better quality, higher productivity and achieving competitive advantage for the firm (Lovelock \& Wright, 2001). Achieving competitive edge by providing value to the customer demands staying distinctive and exceptional in several aspects such quality, systems, speed, services, service processes, etc. than rivals. Making sure this relies on delivering innovations in managerial processes, service processes as well as keeps continuing innovating (Yaşlıoğlu et al., 2013). The innovative practices are key capability for producing services that provide superior customer value. Also, innovative products and process are associated with customer value. Service leaders skilfully bring in their products and services to the marketplace substantially before the expectation of their customers. Furthermore, most of the customers think, a firm retains its leadership position by sticking to the cutting-edge technologies and by stretching out traditional boundaries. Service firms nowadays are likely to please customers by effective use of creative skills and innovation (Nasution and Mavondo, 2008).

In the today's challenging business environment, innovations by itself are of limited importance because its worth is what customers' perceive about the product or service rewards after consuming it. Service innovation results when a firm is in a position to concentrate its complete endeavours on customers for creating impact that exceeds customers' current expectations of higher value. Even the small innovations can bring about outstanding influence and are capable of producing something new and distorting the old. Innovations, hence, nourishes a culture where there can be much less obstacles to the development of partnership of ideas and pursuits on account of the customer. Creative innovations that render higher value to customers are demanded in the competitive marketplace. Hence, customer-focused firms for the benefit of their customers are responsive to new and far better means of carrying out things. Today's customers assume firms should please them with creative products and services. Therefore, creative and innovative innovation performed by a firm regarding their customers is, in fact the sole strategy that preserve the long-term success of the firm (Kandampully, 2002).Hence our next hypothesis is 
H5: Service delivery innovation has positive significant relationship with customer service

\section{Relationship Between Customer Service And Service Quality}

According to S-D logic the ultimate goal of service delivery is to deliver customer service by applying specialized competences like skills and knowledge (Zeithaml and Bitner, 2003; Chen et al., 2009). Also, according to RBV theory firms can attain outstanding performance by possessing and setting up capabilities and resources (Barney, 1991; Chen et al., 2009). Service-oriented firms are recognizing the need to deliver superior customer service to their customers. Due to falling sales and rising competition and far more service-conscious customers are challenging firms to rethink and improve the quality of services which they are delivering. The excellent level of services are very helpful in raising customer retention, building valuable customers, attracting new customers, as well as improving the financial position of organization(Johnston and Clark, 2005). Moreover, firms' endeavours to pay attention to their customers, results in improving overall firms' reputations and positive images. The presence of numerous service channels leads to more satisfied and loyal customers and encourages them to set up long-term relationship with the firm. Furthermore, through this firm attain competitive advantage that, consequently contributes to outstanding financial performance (Chen et al., 2009). Firms' achievement is extremely dependent on the degree to which it could incorporate its knowledge regarding her customers' wants, preferences and needs with their skills, creative potential and intellectual. As a result, competitive edge is acquired by means of intelligent recognition and satisfying customers through superior customer service tools that are swifter and better than rivals (Abiodun, 2008).

The satisfied customers have the likelihood of improving firms' customer base, raise firms' image and enhance the utilization of more unpredictable customer mix. One way to attain customer's satisfaction is via customers' service. Customer service is the provision of service to customers, just before, through and after a purchase order (Abiodun, 2008). Furthermore, due to the intangible nature of services, customers frequently depend on employee's behaviours in developing the image of the service delivery (Gronroos, 1984). Consequently, employees in the customers' eyes, in fact, became fragment of service. Anderson and Sullivan (1993) discovered that across different product categories, there is positive relationship between customers' repurchases intention and satisfaction. Also, satisfied customers were more likely to be retained and loyal. Customer satisfaction can be achieved by keeping service encounters that provide an opportunity to deliver better service quality and differentiate the firm from its competitors ((Abiodun, 2008; Oliver, 1999$)$.

The employees of the firm play important role in promising achievements in the satisfaction and perceptions of the customers', because they are accountable for delivering a quality service that satisfies customers' expectations (Zeithaml et al., 1996). The productive service providers are capable of fulfilling and, whenever feasible go beyond customers' needs and wants in the delivery of their services, because of their peculiar features of services like perishability, variability, intangibility and simultaneity (Armando,2005). According to Kong and Jogaratnam (2007), courtesy and employee personalisation play significant role in the prediction of customer satisfaction. Bulgarella (2005) examined the link between financial triumph and factors involving customers and employees like employees satisfaction, customer satisfaction. He discovered that based on market segment and industry, the relationship between employee behaviour and customer associated factors influence between 40 and 80 per cent on customer loyalty and customer satisfaction. According to Arnette et al. (2002), since the majority of hotels depend on their employees to provide superior service, they could deliver competitive edge to the firm. They further highlighted that customer satisfaction; service quality and loyalty are immensely influenced by the beliefs and behaviours of the employees (Kattara et al., 2008). Thus, we hypothesize the following.

H6: Customer service has positive significant relationship with service quality 


\section{CONCLUSION}

The goal of this paper was to provide the link between service delivery innovation and service quality in services organizations, also establish a conceptual framework and preliminary conceptual model. Researches on service delivery innovation and service quality relationship are nevertheless are hard to find in the literature. Although service industries involvement in economics are increasingly becoming more valuable, handful of researchers have paid attention to the relationship between service delivery innovation and service quality in service organizations. Our recommended model of strengthening service delivery innovation consists of IT capability, relationship and knowledge networks and Dynamic capability. We propose IT capability; relationship and knowledge networks and Dynamic capability exhibit their influence on service quality via the rendering of customer service practices. Authors are of the view that customer service works as a mediator between service delivery innovation and service quality to achieve higher service quality from limited and valuable operant resources.

As reported by Dachyar et al., (2013) innovation affects both perceived service quality and customer value. They discovered that firms should preferably spend time and resources on innovation to improve perceived service quality which in turn influences customer value and these measures needs to be endorsed to all employees. Several Service firms are increasingly being challenged to preserve competitive edge against their competitors to battle against large firms by means of service delivery innovation. This research is meant to shed light on the connections between the components of service delivery innovation, customer service and service quality by offering knowledge into exactly how the management can boost innovation and customers' satisfaction, therefore raising firm's service quality. The managers of the service firms who desire to accomplish outstanding service quality via the inclusion of service delivery innovation practices can increase their firm competitiveness and have the opportunity to take advantage of this research paper.

\section{AUTHOR INFORMATION}

Arif Mohammad Arshad is a doctorate student at the Xi'an Jiaotong University in CHINA.

E-mail: marshadarif@yahoo.com

Dr. QIN SU is a professor in the Faculty of Management Sciences at the Xi' an Jiaotong University in China. E-mail: qinsu@mail.xjtu.edu.cn

\section{REFERENCES}

Abiodun, A. J. (2008). Customer service in the retention of mobile phone users in Nigeria. African Journal of Business Management, 2(2), 026-031.

Abramovici, M., \& Bancel-Charensol, L. (2004). How to take customers into consideration in service innovation projects. The Service Industries Journal, 24(1), 56-78.

Agbor, J. M. (2011). The Relationship between Customer Satisfaction and Service Quality: a study of three Service sectors in Umeå. Umea School of Business, Master's Thesis, two-years, 30hp.

Alam, I. (2006). Removing the fuzzyness from the fuzzy front-end of service innovations trough customer interaction. Industrial Marketing Management, Vol. 35, 468-480.

Anderson, E. W., \& Sullivan, M. W. (1993). The antecedents and consequences of customer satisfaction for firms. Marketing science, 12(2), 125-143.

Anton, C., Camarero, C., \& Carrero, M.(2007) The mediating effect of satisfaction on consumers' switching intention. Psychology \& Marketing, 24,511-538.

Armando,V. ( 2005 ). Delivering Quality Service: All for one?. Journal of Quality Assurance in Hospitality \& Tourism, $6(1 / 2), 25-42$.

Arnette,B., Laverie, A. and Mclane,C. ( 2002 ). Using Job Satisfaction and Pride as Internal Marketing Tools. Cornell Hotel and Restaurant Administration Quarterly, 34(2), 87 -96.

Avlonitis, G. J., Papastathopoulou, P. G. and Gounaris, S. P. (2001). An empirically-based typology of product innovativeness for new financial services: success and failure scenarios. Journal of Product Innovation Management, 18, 324-342.

Bassellier, G., Benbasat, I., Reich, B.H.(2003). The influence of business managers IT competence on championing 
IT. Information Systems Research, 14 (4), 317-336.

Bell, S. J., Auh, S., \& Smalley, K. (2005). Customer relationship dynamics: Service quality and customer loyalty in the context of varying levels of customer expertise and switching costs. Journal of the Academy of Marketing Science, 33,169-183.

Berry, L. L., Parish, J. T., Cadwallader, S., Shankar, V., \& Dotzel, T. (2006). Creating new markets through service innovation. MIT Sloan Management Review, 47(2), 56-63.

Bettencourt, L. A., Brown, S. W., \& Sirianni, N. J. (2013). The secret to true service innovation. Business Horizons, 56(1), 13-22.

Bharadwaj, A. S. (2000). A resource-based perspective on information technology capability and firm performance: an empirical investigation. MIS quarterly, 169-196.

Bhatt, G. D., Grover, V., \& GROVER, V. (2005). Types of information technology capabilities and their role in competitive advantage: an empirical study. Journal of Management Information Systems, 22(2), 253-277.

Bitner, M. J., Brown, S. W., \& Meuter, M. L. (2000). Technology infusion in service encounters. Journal of the Academy of marketing Science, 28(1), 138-149.

Bitner, M., A. Ostrom, F. Morgan. 2008. Service Blueprinting: A Practical Technique for Service Innovation. California Management Review, 50(3), 66-94.

Blazevic, V., \& Lievens, A. (2008). Managing innovation through customer coproduced knowledge in electronic services: an exploratory study. Journal of the Academy of Marketing Science, 36(1), 138-151.

Bon, A. T., \& Mustafa, E. (2013). Impact of Total Quality Management on Innovation in Service Organizations: Literature Review and New Conceptual Framework. Procedia Engineering, 53, 516-529.

Bulgarella,C.(2005). Employee Satisfaction and Customer Satisfaction: Is there a relationship?. A White Paper from Guide Star Research.

Cainelli, G., Evangelista, R. and Savona, M. (2004). The impact of innovation on economic performance in services. Service Industries Journal, 24(1), 116-130.

Chen, J. S., \& Tsou, H. T. (2012). Performance effects of IT capability, service process innovation, and the mediating role of customer service. Journal of Engineering and Technology Management, 29(1), 71-94.

Chen, J. S., Tsou, H. T., \& Huang, A. Y. H. (2009). Service delivery innovation antecedents and impact on firm performance. Journal of Service Research, 12(1), 36-55.

Cronin, J. J., Jr., Brady, M. K., \& Hult,G.T. M. (2000). Assessing the effects of quality, value, and customer satisfaction on consumer behavioural intentions in service environments. Journal of Retailing, 76, 193-218.

Dachyar, M., Rusli, M. S., \& Zagloel, T. Y. M. (2013). The Role of Innovation Management Model to Improve Service Quality for Telecommunications Industry in Indonesia. Innovative Systems Design and Engineering, 4(4), 1-6.

Danjum, I., \& Rasli, A. (2012). Imperatives of service innovation and service quality for customer satisfaction: Perspective on higher education. Procedia-Social and Behavioral Sciences, 40, 347-352.

Dawson, R., \& Horenkamp, M. (2007). Service Delivery innovation: Creating client value and enhancing profitability. SAP America Inc.

Day, G. S., \& Wensley, R. (1988). Assessing advantage: a framework for diagnosing competitive superiority. The Journal of Marketing, 1-20.

Dean, A. M. (2002). Service quality in call centres: implications for customer loyalty. Managing Service Quality, 12(6), 414-423.

Evangelista, R., \& Sirilli, G. (1998). Innovation in the service sector results from the Italian statistical survey. Technological Forecasting and Social Change, 58(3), 251-269.

Flint, D.J. and Mentzer, J.T. (2000). Logisticians as marketers: their role when customers' desired value changes. Journal of Business Logistics, 21(2), 19-45.

Gaynor, G.H. (2002). Innovation by Design: What it Takes to Keep Your Company on The Cutting Edge. AMACOM American management association, New York, NY.

Grawe, S. J., Chen, H., \& Daugherty, P. J. (2009). The relationship between strategic orientation, service innovation, and performance. International Journal of Physical Distribution \& Logistics Management, 39(4), 282-300.

Grönroos, C. (1982). Strategic Management and Marketing in the Service Sector. Swedish School of Economics and Business Administration, Helsingfors, Finland, (published in 1983 in the US by Marketing Science Institute and in the UK by Studentlitteratur/ Chartwell-Bratt).

Grönroos, C. (1984). A service quality model and its marketing implications. European Journal of marketing, 18(4), $36-44$. 
Gronroos, C. (1990). Service Management and Marketing. Lexington Books, Lexington, MA

Grönroos, C. (2000). Service Management and Marketing: A Customer Relationship Approach(2nd ed.).Wiley, Chichester.

Guo, L., Xiao. J.J., Tang, C. (2009).Understanding the psychological process underlying customer satisfaction and retention in a relational service. Journal of Business Research, 62(11), 1152-1159

Gustafsson, A., Ekdahl, F. and Edvardsson, B. (1999). Customer focused service development in practice. A case study at Scandinavian Airlines Systems (SAS). International Journal of Service Industry Management, 10(4), 344-358.

Hunt, Shelby D. (2000). A General Theory of Competition: Resources, Competences, Productivity, and Economic Growth. California, Thousand Oaks: Sage Publications.

Hurley, R. F., \& Hult, G. T. M. (1998). Innovation, market orientation, and organizational learning: an integration and empirical examination. The Journal of Marketing, 42-54.

Hurley, Robert F. and G. Tomas M. Hult (1998). Innovation, Market Orientation, and Organizational Learning: An Integration and Empirical Examination. Journal of Marketing, 62 (3), 42-54.

De Jong, J. P., \& Vermeulen, P. A. (2003). Organizing successful new service development: a literature review. Management decision, 41(9), 844-858.

Johnston, R. and Clark, G. (2001). Service Operations Management. Pearson Education Ltd, Essex.

Johnston, R. and Clark, G. (2005). Service Operations Management: Improving Service Delivery( 2nd ed.). Financial Times Prentice-Hall, Harlow.

Kadir, H. A., Rahmani, N., \& Masinaei, R. (2011). Impacts of service quality on customer satisfaction: study of online banking and ATM services in Malaysia. International Journal of Trade, Economics and Finance, 2(1), 1-9.

Kandampully, J. (2002). Innovation as the core competency of a service organisation: the role of technology, knowledge and networks. European Journal of Innovation Management, 5(1), 18-26.

Kattara, H. S., Weheba, D., \& El-Said, O. A. (2008). The impact of employee behaviour on customers' service quality perceptions and overall satisfaction.Tourism and Hospitality Research, 8(4), 309-323.

Kaufman, A., Wood, C. H., \& Theyel, G. (2000). Collaboration and technology linkages: a strategic supplier typology. Strategic Management Journal, 21(6), 649-663.

Kettinger, W. J., \& Lee, C. C. (1994). Perceived service quality and user satisfaction with the information services function*. Decision sciences, 25(5-6), 737-766.

Kong,M. and Jogaratnam,G. ( 2007 ).The Influence of Culture on Perceptions of Service Employee Behavior . Managing Service Quality, 17, 3, 275 - 297.

Lai, F., Griffin, M., \& Babin, B.J. (2009). How quality, value, image, and satisfaction create loyalty at a Chinese telecom. Journal of Business Research, 62(10): 980-986.

Leiponen, A. (2006). Managing Knowledge for Innovation: The Case of Business-to-Business Services*. Journal of Product Innovation Management, 23(3), 238-258.

Leonard L. Berry, and A. Parasuraman (1988). Communication and Control Processes in the Delivery of Service. Journal of Marketing, 52 (2), 35-49.

Lievens, A. and Moenaert, R. K. (2000). Project team communication in financial service innovation. Journal of Management Studies, 37(5), 733-766.

Lievens, A., Moenaert, R. K., \& Jegers, R. S. (1999). Linking communication to innovation success in the financial services industry: a case study analysis. International Journal of Service Industry Management, 10(1), 2348.

Lin, L. (2011, June). The impact of service innovation on business performance: Evidence from firm-level data in Chinese tourism sector. In Service Systems and Service Management (ICSSSM), 2011 8th International Conference on (pp. 1-5). IEEE.

Lovelock, C., \& Wright, L. (2001). Principles of service marketing and management. Prentice Hall.

Lusch, R. F., \& Vargo, S. L. (2006). Service-dominant logic: reactions, reflections and refinements. Marketing theory, 6(3), 281-288.

Lusch, R. F., Vargo, S. L., \& O’Brien, M. (2007). Competing through service: insights from service-dominant logic. Journal of retailing, 83(1), 5-18.

Lusch, R. F., \& Vargo, S. L. (2006). Service-Dominant Logic as a Foundation for a General Theory', in R.F. Lusch and S.L. Vargo (eds) The Service-Dominant Logic of Marketing: Dialog, Debate, and Directions. Armonk, NY: ME Sharpe 
Lusch, R. F., Vargo, S. L., \& O’Brien, M. (2007). Competing through service: Insights from service-dominant logic. Journal of retailing, 83(1), 5-18.

Mascitelli, R. (2000). From experience: harnessing tacit knowledge to achieve breakthrough innovation. Journal of product innovation management, 17(3), 179-193.

Matear, S., Grey, B. J. and Garrett, T. (2004). "Market orientation, brand investment, new service development, market position and performance for service organizations." International Journal of Service Industry Management, 15(3), 284-301.

Matthing, J., Sandén, B., \& Edvardsson, B. (2004). New service development: learning from and with customers. International Journal of Service Industry Management, 15(5), 479-498.

Michel, S., Brown, S.W., Gallan, A.S.(2008). Service-logic innovations: how to innovate customers, not products. California Management Review, 50 (3), 49-65.

Michel, S., Brown, S. W., \& Gallan, A. S. (2008). An expanded and strategic view of discontinuous innovations: deploying a service-dominant logic. Journal of the Academy of Marketing Science, 36(1), 54-66.

Narver, J.C. and Slater, S.F. (1990).The effect of a market orientation on business profitability. Journal of Marketing, 54(4), 20-35.

Nijssen, E. J., Hillebrand, B., Vermeulen, P. A., \& Kemp, R. G. (2006). Exploring product and service innovation similarities and differences. International Journal of Research in Marketing, 23(3), 241-251.

Oliver, R. L. (1999). Whence consumer loyalty?. the Journal of Marketing, 33-44.

Ordanini, A., \& Parasuraman, A. (2011). Service innovation viewed through a service-dominant logic lens: a conceptual framework and empirical analyses. Journal of Service Research, 14(1),3-23.

Parasuraman, A., Zeithaml, V. A., \& Berry, L. (2004). SERVQUAL: a multiple-item scale for measuring consumer perceptions of service quality. Retailing: Crit Concepts Bk2, 64(1), 140.

Parasuraman, A., Zeithaml, V., \& Berry, L. (2002). SERVQUAL: a multiple-item scale for measuring consumer perceptions of service quality. Retailing: critical concepts, 64(1), 140.

Parasuraman, A., Zeithaml, V.A. and Berry, L.L. (1988), SERVQUAL: a multi-tem scale for measuring customer perceptions of service quality. Journal of Retailing, 64(1), 12-40.

Pitt, L.F., Watson, R.T., \& Kavan, C.B., (1995). Service Quality: A Measure Of Information Systems Effectiveness. MIS Quarterly, 173-187.

Prahalad, C. K., \& Ramaswamy, V. (2004). Co-creating unique value with customers. Strategy and Leadership, 32(3), 4-9.

Ross, J. W., Beath, C. M., \& Goodhue, D. L. (1996). Develop long-term competitiveness through IT assets. Sloan management review, 38(1), 31-42.

Ross, J. W., Beath, C. M., \& Goodhue, D. L. (1996). Develop long-term competitiveness through IT assets. Sloan management review, 38(1), 31-42.

Sachdev, S. B., \& Verma, H. V. (2004). Relative importance of service quality dimensions: a multisectoral study. Journal of services research, 4(1), 93-116.

Samat, N., Ramayah, T., \& Saad, N. M. (2006). TQM practices, service quality, and market orientation: some empirical evidence from a developing country. Management Research News, 29(11), 713-728.

Santos, J. (2003) E-Service Quality: A Model of Virtual Service Quality Dimensions. Managing Service Quality, 13(3): 233-46.

SChILLING, A. N. N. I. K. A., \& Werr, A. N. D. R. E. A. S. (2009). Managing and organizing for innovation in service firms. VINNOVA Report VR 2009, 6.

Schlegelmilch, B. B., Diamantopoulos, A., \& Kreuz, P. (2003). Strategic innovation: the construct, its drivers and its strategic outcomes. Journal of Strategic Marketing, 11(2), 117-132.

Schulteß, P., Wegener, S., Neus, A., \& Satzger, G. (2010). Innovating for and with your service customers: An assessment of the current practice of collaborative service innovation in Germany. Procedia-Social and Behavioral Sciences, 2(4), 6503-6515.

Siguaw, J. A., Simpson, P. M., \& Enz, C. A. (2006). Conceptualizing Innovation Orientation: A Framework for Study and Integration of Innovation Research*. Journal of Product Innovation Management, 23(6), 556-574.

Simme, J. (2004). Innovation Networks and Learning Regions?. Routledge.

SIMPSON, P. M., SIGUAW, J. A. \& ENZ, C. A. (2006). Innovation orientation outcomes: The good and the bad. Journal of Business Research, 59, 1133-1141.

Stark, J. (2011). Product lifecycle management. Springer London.

Tether, Bruce S. (2002). Who Cooperates for Innovation, and Why? An Empirical Analysis. Research Policy, 31 (6), 
947-968.

Tinnilä, M., \& Vepsäläinen, A. P. (1995). A model for strategic repositioning of service processes. International Journal of Service Industry Management, 6(4), 57-80.

Vargo, S. L., Maglio, P. P., \& Akaka, M. A. (2008). On value and value co-creation: A service systems and service logic perspective. European management journal, 26(3), 145-152.

Vargo, S. L., \& Lusch, R. F. (2004). Evolving to a new dominant logic for marketing. Journal of marketing, 68(1), 117.

Vargo, S. L., \& Lusch, R. F. (2008). Service-dominant logic: continuing the evolution. Journal of the Academy of marketing Science, 36(1), 1-10.

Verma, R., \& Jayasimha, K. R. (2014). Service delivery innovation architecture: An empirical study of antecedents and outcomes. IIMB Management Review.

Victorino, L., Verma, R., Plaschka, G., \& Dev, C. (2005). Service innovation and customer choices in the hospitality industry. Managing Service Quality, 15(6), 555-576.

Walker, R. H., Craig-Lees, M., Hecker, R., \& Francis, H. (2002). Technology-enabled service delivery: an investigation of reasons affecting customer adoption and rejection. International Journal of Service Industry Management, 13(1), 91-106.

Woodruff, R.B. (1997). Customer value: the next source for competitive advantage. Journal of the Academy of Marketing Science, 25(2), 139-53.

Yaşlıoğlu, M., Çalışkan, B. Ö. Ö., \& Şap, Ö. (2013). The Role of Innovation and Perceived Service Quality in Creating Customer Value: A Study on Employees of a Call Center Establishment. Procedia-Social and Behavioral Sciences, 99, 629-635.

Yoo, D.K., Park, J.A. (2007.) Perceived service quality - analysing relationships among employees, customers, and financial performance. International Journal of Quality \& Reliability Management, 24 (9), 908-26.

Zeithaml, V. and Bitner, M. (2000). Services Marketing: Integrating Customer Focus across the Firm (2nd ed.). the McGraw-Hill Companies Inc., New York, NY.

Zeithaml, V. A., Berry, L. L., \& Parasuraman, A. (1996). The behavioral consequences of service quality. the Journal of Marketing, 31-46. 


\section{NOTES}

